Participatory Educational Research (PER)

Special Issue 2015-II, pp., 99-109; 5-7 November, 2015

Available online at http://www.partedres.com

ISSN: 2148-6123

http://dx.doi.org/10.17275/per.15.spi.2.12

\title{
Development of Mobile Learning Material for 9th Grade Physics Course To Use in FATIH Project: Force and Motion Unit
}

\author{
Mahmut Kantar * and Mevlüt Dogan \\ Department of Physics, Afyon Kocatepe University, Afyonkarahisar, Turkey
}

\begin{abstract}
Curriculum and course books have an important role in teaching process. But they are not sufficient as course materials on their own. It is known that Information Technologies make big impacts on teaching process. As these technologies have become mobile today, it is a necessity to develop and use mobile learning materials. In FATIH project it is aimed to enhance the information technology infrastructure and students to have technological tools. But in the project process, the lack of materials which students can use, is remarkable.

Lately usage of mobile phones and tablet computers is increasing because of the Internet. Increase in mobile internet usage led to developing with different tools than traditional web sites uses. In this context instead of traditional web pages, developing and using mobile applications is inevitable.

Developing mobile content process consists of 3 basic levels. These are: design, develop and publish. Each level is split up into own work routines. In design process, especially writing scenario and designing storyboard are essential steps of work routine. In developing process different methods and tools can be used. Producing products for both mobile applications and for internet is a preference criteria in choosing developing tool.

Mobile content can be prepared by basic programming knowledge. For these content software like "Adobe Flash", "Creative Book Builder", "TouchAppCreator", "EduCreation", "Explain Everything" can be used. In this research acquisition-based mobile contents of the unit "Force and Motion" which is included in the curriculum of 9th grades are prepared using "Adobe Flash CS6" software. This application will be the first and an example for other units. Developed content was used by teachers and students and their opinions have been taken into consideration.
\end{abstract}

Keywords: Interactive learning environments; content design; mobile learning, Force and Motion

\section{Introduction}

At all levels of education, computerized education and training is increasing day by day. Students who meet with the information technology at the university in previous years now meet it at primary school period and they can use many information technologies. 
The physics curriculum taught in high schools in our country is revised in 2013. On the basis of this program, meaningful learning in physics classes should take place in an environment which controls the validation of students' prior knowledge, in which students are mentally and physically active and which aims at providing a conceptual change (Kantar, 2014).

Laboratories are one of the most basic environments, students are both physically and mentally active in teaching physics subjects. In the experiments that are performed in the lab, students engage in mental activities through developing a hypothesis, testing their hypothesis, getting results and interpreting the results. During the practice stage of the experiment manual skills are used effectively in processes as organizing mechanisms or taking measurements.

Laboratories have an important place in the teaching of Physics. However, the fact that the education system in Turkey is exam-oriented, there is competition among students, success is perceived only as the exam grades, and in this case, a loss of interest in laboratories is a remarkable detail. In addition, the fact that many of the physics experiments are time consuming and that they cannot fully reflect the required physical event decrease the interest in physics laboratories. In some cases, the desired physical event cannot be easily observed experimentally. Processes such as removing an electron from the cathode of light in a photoelectric experiment are not observable by the eye. It is possible to make such subjects that cannot be described by the laboratory methods in physics education visible and understandable by simulations and animations (Bozkurt \& Sarıkoç, 2008).

The information technology which provides a wide range of opportunities with modelling, animation, and simulations has become an indispensable tool in education through images, audio, and interactive components especially in events that are difficult to explain and understand. In this context, computer and ICT-assisted learning environments for teaching physics with a wide variety of learning techniques can be developed (Bozkurt \& Sarıkoç 2008).

In addition to teaching strategies, while preparing content pedagogy should be kept in mind. Pedagogy and content should be considered together (Keller, 2004). Pedagogical dimension of e-learning covers many topics related to teaching and learning. These are: content analysis, student analysis, goal analysis, media analysis, design approach and organization, learning strategies and mix strategies (Hakkari, 2009; Hakkari et al., 2009; İbili et al., 2009). Elearning is a student-centred learning style. Being student centred requires beginning with the student analysis.

Storyboard is a visual expression method frequently referenced not only in movies or advertisements which are made of a lot of scenes, but also in areas where information technologies such as animation and programming are used (Kantar 2014). In scenario there is a written statement that expresses how the incident occurred while more visual drafts can be prepared using visual thumbnails on the storyboard. Many studios talk about the connection of the storyboard with professionalism. "Storyboard is an idea, a bridge between the result and concept and a visual form of communication." (Hakkari 2009).

Choosing the characters to be used in animations, animation environment, the materials to be used, text and animation areas, the directive that will allow students to communicate with the mobile device needs to be standard. Therefore, the screen display should be optimized according to the type of mobile device and resolution (Kantar et al. 2015). 


\section{General Concepts}

\section{The need for E-Learning}

Technology and informatics equipment should be used for transferring information by expert educators in educational institutions and in improving the quality of teaching and the learning environment. All educational technologies are learning tools. Education technology can be used as a good tool to create meaningful learning as permanence and activity are at the foreground (Kurt 2006). With the developments in information technology in recent years; computer animation, audio and visual material, such as simulation are improved and these materials have been often used in training. Therefore, computer-supported and computerbased training concepts have emerged.

Animation is defined as "The study of editing and filming individual pictures or stationary bodies in a format to give a sense of movement during playback" by Turkish Language Institution (Kantar, 2015). More explicitly, animation is "Creating lots of stationary image that can make an object seem to move and playing these images in quick succession so as to enable us to think that it really moves" (Arıcı \& Dalkılıç 2006).

The rapid growth of information and the number of students has revealed a number of problems such as lack of teachers. These problems has shown that new technology should be used in education and training (Özel 2008). Due to the difficulties encountered in the education of students with different learning levels, it is understood that the traditional approach isn't enough and it has become a necessity to lead to new pursuits. These needs and search, can be stated as the main reason for information tools and equipment to enter the education process.

\section{E-Learning Algorithm Workflow}

E-learning algorithm workflow principally consists of three stages; design, develop and publish (Polat 2014).

These processes should be carried out by a group consisting of a few people per each process at this stage. These phases can be listed as follows:

- The text to be converted to e-content should be prepared.

- This text is scripted by a specialist educational designer.

- Scenario text is transformed into a storyboard with thumbnails.

- Character and environment is designed.

- Animation and simulation is prepared.

- Resources like sound, video, pictures, link and etc. are prepared.

- Scene and materials comes alive on the screen on the player.

- The product is published certified in "Apk" format.

\section{Scenario}

Scenario is the text version of the image and audio showing the scene and flow of an event or a thought in cinema, television and the IT sector. 
Scenario is the first step in preparing a film or animation. As Alfred Hitchcock once said, "3 things you need to take a good movie: the script, script and screenplay." If you have a good story to tell you will need a good script.

Scenario is a bridge between a training designer and an animation designer. The person preparing the script should look from different perspectives. The scenario should be prepared from the eyes of all individuals involved.

During the production stage, from the angle of instructional designer, artist, voice element and programmer, also as customers; you need to look with the eyes of students and teachers. During the writing phase the writer should create a theme that can facilitate the work of all actors.

\section{Storyboard}

Storyboard, is the screen by screen description of the things people would see, hear and act in the story in the writer's mind.

Storyboard is a frequently used form of visual expression that is used in the animation scenes as well as in the scenes of movies and theatre. There should be information as the voice, video, link and etc. under the related frames in the scenario prepared. Previously prepared scenarios are described with visual and auditory features on the storyboard screen.

Converting the scenario into a draft in the format of a storyboard would help the person who will prepare the animation to have an idea about what to do. The animation process is sometimes too long. Before you start the animation, displaying the movements to be made on the screen of the storyboard will prevent the loss of time to in the future.

While drawing the storyboard, the event to be acted out in the scene should be laid out in a format that is understandable. If you have an event that is desired to be specifically addressed in the scene, it should be reflected in the frame in detail. Improvisation should not be done. Storyboard can be drawn with a pen on a paper or it can be prepared with various computer programs. There are programs available for this, such as Storyboard Quick, Storyboard Artist, Boardmaster and so on.
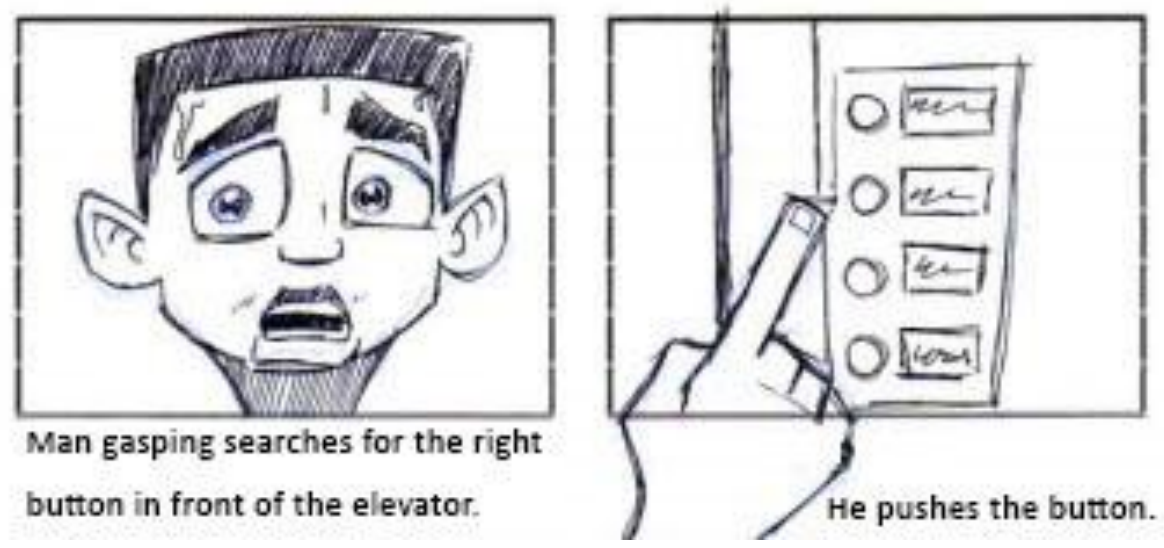

Figure 1. Storyboard sample (MEGEP 2007). 


\section{Materials AND Methods}

The infrastructure of information technology and the needs and desires of the target audience should be taken into consideration while preparing educational activities. The activity or content prepared in this stage needs to find answers to these questions;

- What kind of a technological environment should we work in?

- Who is the target audience?

- What are the needs?

In this study, for the unit "Force and Motion";

- 66 scenarios for the 13 gains located in the "Motion in one dimension" section,

- 26 scenarios for the 8 gains located in the "Force" section,

- 28 scenarios for the 10 gains located in the "Newton's laws of motion"

are written and these scenarios are transformed into a storyboard.

\section{Stage Design and Specifications}

Animations, text fields, writing styles of textual expressions that will be used in the scene and standards for references were determined. The size of the stage was determined and tested on different tablet and mobile devices and the most appropriate size was determined. The mobile device was arranged for all the scenes to be used in horizontal form.

Table1 : Technical characteristics of the scene.

\begin{tabular}{ll}
\hline Type & Explanation \\
\hline Screen size & $1000 \mathrm{px}-550 \mathrm{px}$ \\
Player & AIR 3.2 for Android \\
Dubbing & All scenes will be performed. \\
Animation & Drawing will be held on the screen. \\
Text style & Calibri, 14 px, Regular, Black \\
The background color of the text field & \#CCCCC \\
The border color of the text field & \#999999 \\
Directive style & Calibri, $14 \mathrm{px}$, Regular, Black. \\
Reference style & Calibri, 12 px, Regular, Black. \\
\hline
\end{tabular}

Textual expressions on mobile device screens are more difficult to read compared to those in other written materials. Therefore, the font of the text to be used, its size and color are important. The background color of the textual expression and frame color are also important. It can cause problems in perception when the background color of the textual expression and the border color are more attractive than the text itself. In this context, text field and its contents are considered as a whole. 
Scene 49: Straight Line Motion Graphs - Phy $931542 \longrightarrow\{$ Screen Tag $\}$
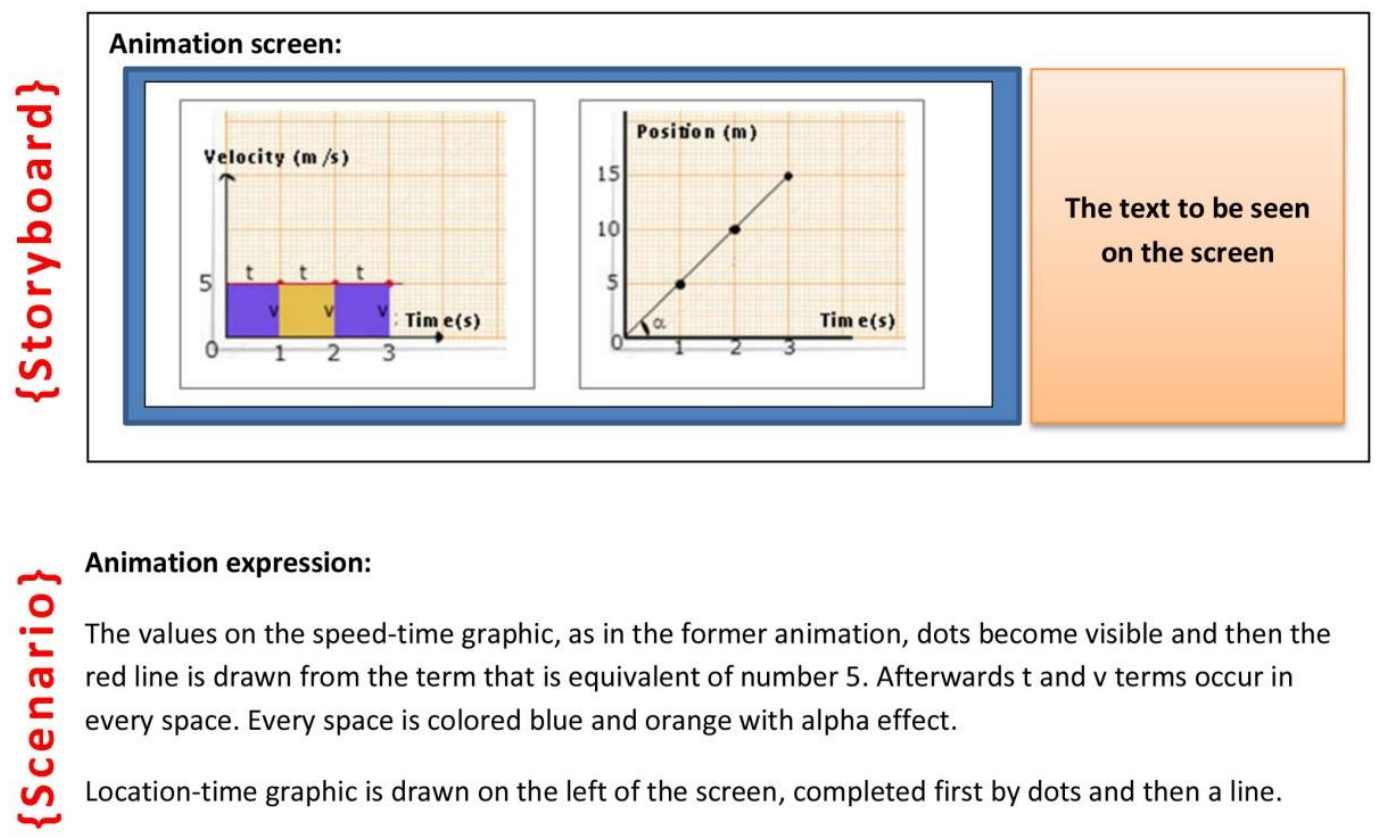

The text to be seen on the screen:

Conversion of motion graphics to each other:

As the inclination of the location-time graphic gives us the speed value, we can infer how to draw a speed-time graphic.

In the animation area next, in each one of the blue and orange areas the horizontal axis shows the time and the vertical axis shows the speed. If we want to calculate the area for each slice, we come up with a v.t correlation. Multiplication of these terms gives us the exchanging of places. That means, the area under the speed-time graphic gives us the exchanging of places. With the help of this data, it is possible to draw a location-time graphic for each situation.

\section{Directive:}

- Click on the next button to continue. $\longrightarrow\{$ Directive

Figure 2. The example scenario design

The example scenario design in Figure 2 consists of five main stages. These are display label, storyboard, scenario, text and the instructions.

- Screen Tag: Area of screen tag, consists of 3 parts. In the first part, the number of the generated scene takes place. The expression situated on the second part illustrates unit subtitles. The third part includes the name of the file where the scene will be saved.

- Storyboard Area: Visually tells the story of an animation display by display.

- Scenario Area: Includes the details of the activity that will take place in the storyboard area.

- Text Area: Textual phrases are displayed in this section. 
- Directive area: Sentences that express what to do within the activity or during the phase of passing to the next stage.

\section{The player screen and activity Icons}

Primarily, player display was prepared. All the scenes were collected together in the player screen. A design in the form of a board that emphasizes the school theme was thought for this design. The directive buttons to the player screen were placed.

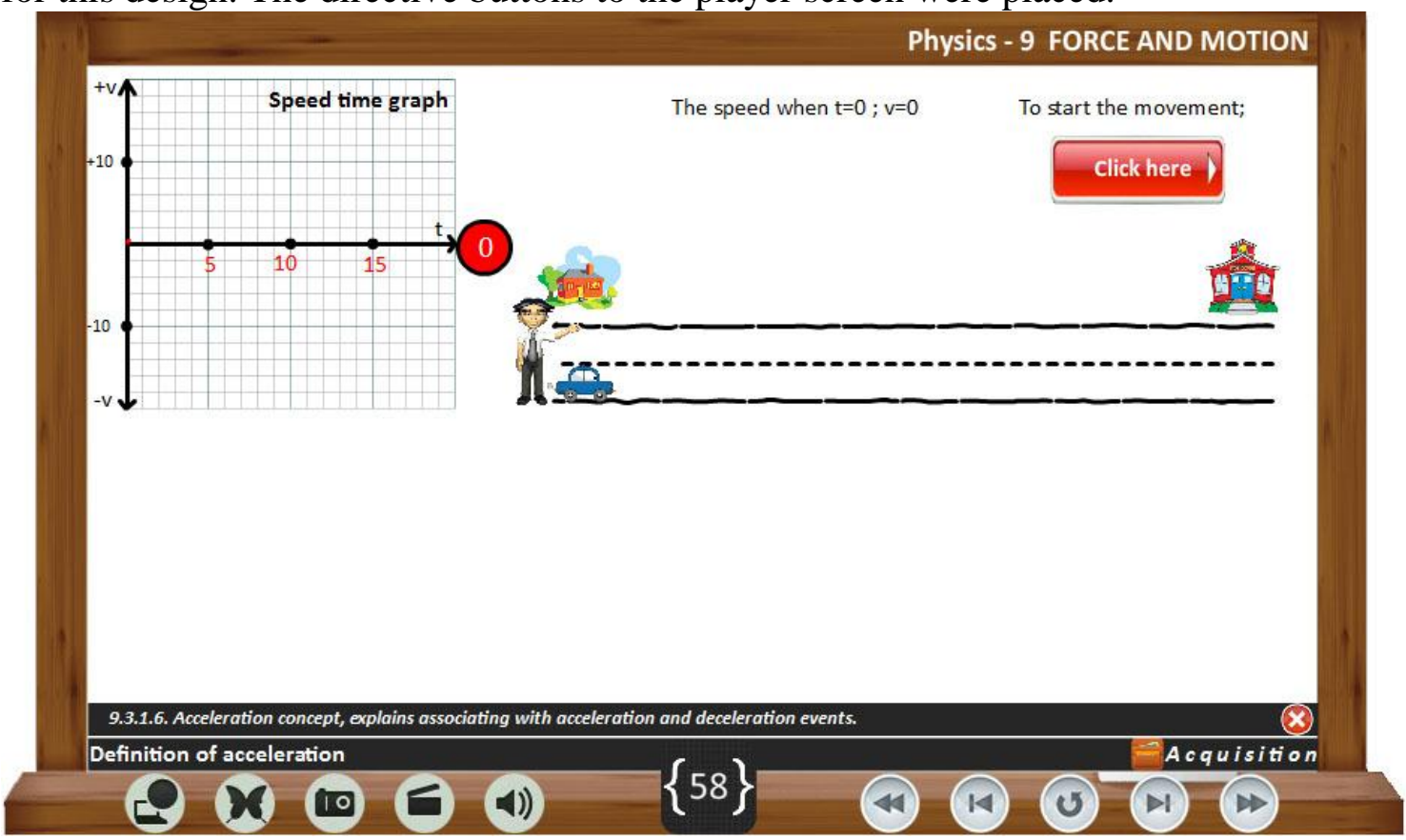

Figure 3. The scene view.

In figure 3, at the top right of the player screen the name of the unit is located. Under the stage gains and subheadings are located. Gain bar cannot be imaged initially, but once you click on the appropriate button it is visible. It can be removed from the screen. The lower part of the screen is divided into three sections. The left section is the activity area, the middle part is counter and the directive buttons are located in the right section.

Table 1:The player screen activity icons and descriptions

$\begin{array}{lll}\text { Icons Icon name } & \text { Description } \\ \text { Gink } & \text { Go to any web page link related to the scene. } \\ \text { If there is a simulation screen relevant to the scene, calls the simulation on the screen. } \\ \text { If one or a few pictures should be shown at the related scene, it brings them to the } \\ \text { screen as pop-up windows. } \\ \text { If video motion should be shown at the related scene, it brings it to the screen as pop- } \\ \text { up windows. } \\ \text { If there will be vocalization at the scene, when the audio button is clicked, the } \\ \text { vocalization is made. }\end{array}$


If student wants to listen to vocalization they must click on the audio button. Similarly, if there is video, photo, or simulation in connection with the scene it can be seen by clicking on the buttons.

Table 3: Directive icons.

\begin{tabular}{|c|c|c|}
\hline Icons & Icon name & Description \\
\hline & First & Provides to return to the first screen scene. \\
\hline & Previous & Provides to return to the previous scene. \\
\hline & Repeat & Allows the scene to be shown again. \\
\hline & Next & Provides to go to the next scene. \\
\hline & Last & Provides to go to the last scene. \\
\hline
\end{tabular}

While designing educational material, it is considered to be appropriate for the $9^{\text {th }}$ grade students. A model student was discussed at the character selection. For this student, different position views were created. Laboratory and classroom designs to be used in the scene were made. Materials to be used in these environments were collected and placed in the required fields.

In the third stage of the study, appropriate character and materials were placed in the scene prepared. For this Adobe Flash CS6 was used. The reasons of using Adobe Flash CS6 are as follows.

- The application makes it possible to import different material types in it,

- It is possible to run the output of the prepared product in different environments such as the web and mobile devices,

- To be able to exchange data in coordination with numerous programs,

- The file size of the resulting product occupies less space compared to similar products,

- The fact that the player screen, animation and voice over can be integrated with a single program,

- The applications can be made for mobile devices.

\section{Process of preparing animation}

Coding for mobile applications, must be made as "Action Script 3.0". In this context, "Adobe Flash CS6" or more developed versions were preferred. Animated images prepared for scenes, was designed separately as "Movie Clip" object. With this method, the "MovieClip" objects created were used in many common scenes. The benefit of using "Movie Clip" objects is the smaller file size. Similarly, objects for common buttons in the scene were created. Movie Clip and the buttons were displayed on the screen with the reflection method. So, the file size problem, which should be considered particularly in mobile applications, was reduced. 


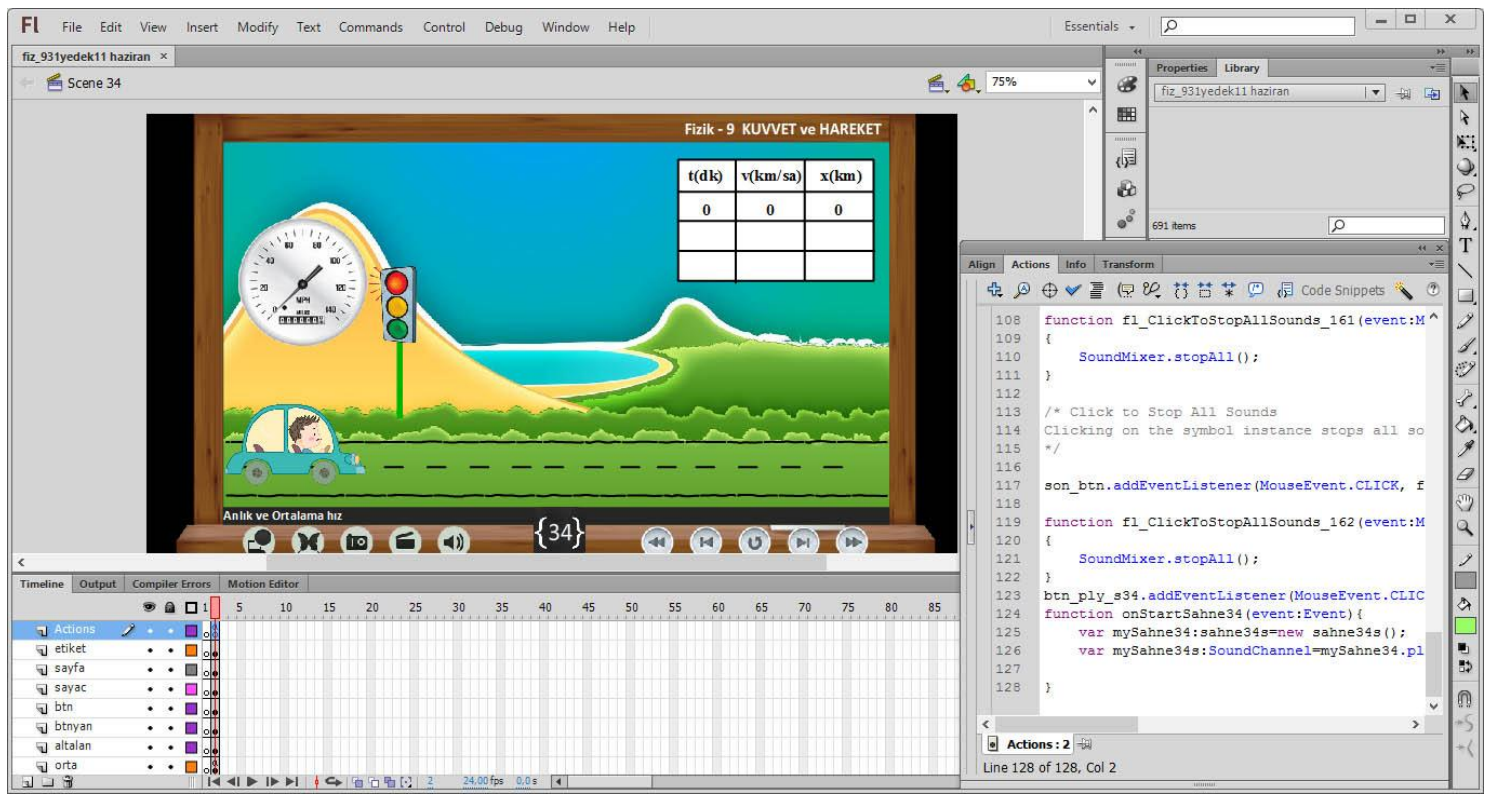

Figure 4. Adobe Flash CS6 code implementation.

\section{Publishing of Animations}

Adobe Flash Professional CS 5.5 and later versions allow you to publish content for Adobe AIR for Android. The AIR (Adobe Integrated Runtime) platform, gives designers and developers using "Adobe Flash CS6" a way to use their existing skills to create cross-platform desktop applications. Users can download the AIR runtime for free and install it to manage and play AIR applications directly from their desktops or mobile device.
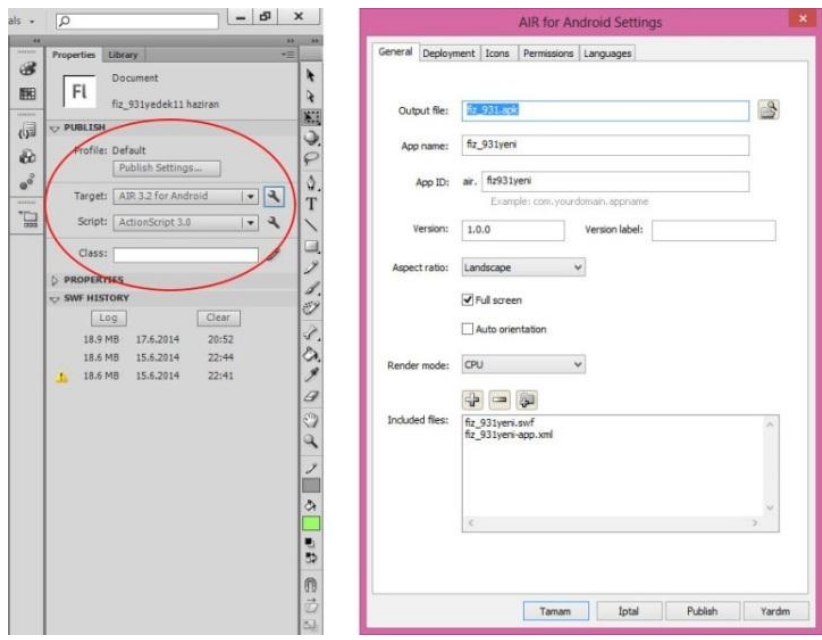

Figure 5. Publish Settings.

- Output file: Select a filename and location for your published AIR application.

- App Name: Your application displays this name when it's installed and when it's running on mobile device. 
- Version: This option show which version of an application is installed or running.

- Aspect Ratio: Allows you to select Portrait, Landscape, or Auto orientation for the application. When Auto is selected along with Auto orientation, the application launches on the device depending on its current orientation.

- Render Mode: Make a decision whether or not AIR should render the application with your graphics processing unit (GPU) or the main central processing unit (CPU).

- Included Files: Define which supplementary files and folders to include in your application package. Click the Plus (+) button to add files and the folder button to add folders.

\section{Results}

At the beginning of the study, the textbooks prepared in accordance with the 2013 curriculum taught in schools were examined. After this examination, scenario writing and storyboard drawings was made including all textbooks, which, in a sense, can be referred to as enhanced books. In this study, the project was completed using an interactive environment enriched with visual themes that provide more information instead of theoretical knowledge in the physics books. In this sense, it is possible to show it as a model for other work to be done.

$9^{\text {th }}$ grade physics curriculum, covers the basic concepts located in the physical sciences. In this study, it has been targeted for students to acquire conceptual and procedural knowledge related to physical sciences and apply these skills to new situations. Mobile application scenarios prepared in line with these objectives made it possible for students to use their knowledge and skills in education and to establish relations with new situations.

In the literature, in line with the curriculum in 2013, an academic material development study has not been found. It is known that there is a need of content for the Tablet PC distributed within the scope of "FATIIH" project. This study is the first acquisition based course material appropriate for the latest curriculum. In this study, Android-based courses are created for mobile devices. In the study itself;

- Preparation of scenario and storyboards

- Making the character and environment design

- Processing with Adobe Flash CS6

- Calling the animations on the player screen

- The integration of activities such as photo, video, audio and etc. to the scene

- Content packaging

For easy access to the prepared course materials "mobilfizik.aku.edu.tr" address is acquired. At this address; "apk" android file and "html" file types are published. The prepared content will be helpful for students who need special education in terms of support for education as part of equity of opportunities. This study can be evaluated in the scope of individualized training. In particular, it will contribute to the education of disadvantaged groups. 


\section{References}

Anonim, (2007). Mesleki eğitim ve ögretim sisteminin güçlendirilmesi projesi,. grafik ve fotoğraf alant storyboard, [Strengthening project of vocational education and training system, the field of photography, graphics and storyboard] Ankara.

Arıcı, N. ve Dalkılıç, E. (2006). Animasyonların bilgisayar destekli ögretime katkısı: bir uygulama örneği.[Contribution of animations to computer aided education: an application sample]. Kastamonu Eğitim Dergisi, 14(2): 421-430.

Bozkurt, E., Sarıkoç, A., (2008). Fizik ĕgitiminde sanal laboratuar, geleneksel laboratuarın yerini tutabilir mi?. [Virtual laboratory in physics education, can replace traditional lab?]. Selçuk Üniversitesi Ahmet Keleşoğlu Eğitim Fakültesi Dergisi, 25: 89 -100.

Hakkari F., (2009). Uzaktan eğitim ders materyali hazırlamada içerik tasarımı, senaryo hazırlama ve uygulamast. [ Preparation of course material for distance education content design, script preparation and application] (Master's Thesis), Afyon Kocatepe University.

Hakkari F., Kantar M., Bayram F., İbili E., Doğan M., (2009), Ders notlarının senaryolaştırlmast ve uygulaması. [ Screenplay and implementation of the course material.] Akademik Bilişim 2009, Harran University, 11-13 Şubat, 269-276, Şanlıurfa.

İbili E., Bayram F., Hakkari F., Kantar M., Doğan M., (2009), SCORM Uyumlu eğitim yönetim sisteminin tasarlanmast ve üniversite bazında uygulanmast.[ Designing SCORM compliant learning management system and implementation on the basis of the University], Akademik Bilişim 2009, Harran University, 11-13 Şubat, 277-286, Şanliurfa.

Kantar, M. (2014) Fatih projesi paralelinde 9. sinif fizik dersi kuvvet ve hareket konusunda ders materyalleri geliştirme.[ Developing teaching materials for $9^{\text {th }}$ grade physics in force and motion unit with path of fatih project] (Master's Thesis). Afyon Kocatepe University.

Kantar, M., Dogan, M., (2015). 9. Sınıffizik dersi ögretim programının kazanım temelli olarak ders notlarının senaryolaştırılmast: Kuvvet ve hareket ünitesi örneği. [Designing screenplays of $9^{\text {th }}$ grade gain based cirruculum physics lesson material: Sample of force and motion ]. Instructional technologies \& teacher education symposium. ITTES 2015, Trabzon

Keller, J.M., Suzuki, K., (2004). Learner Motivation and E-learning Design: A Multinationally Validated Process, Journal of Educational Media, 29: 3, 229-239

Kurt, A. İ., (2006). Anlamlı öğrenme yaklaşımıma dayalı bilgisayar destekli 7. sınıffen bilgisi dersi için hazırlanan bir ders yazılımının öğrencilerin akademik başarılarına ve kalıcılığa etkisi. [The effect of the software based on meanningful learning approach and assisted computer prepared for science course on the seventh grade students' academic achievement and retention.]. (Master's Thesis), Çukurova University, Adana.

Özel, S. F., (2008). Bilgisayar destekli ögretim materyallerinin öğrencilerin tutum ve başarllarına etkisi. [Impact of computer-aided instructional materials on student attitudes and achievement.] (Master's Thesis), Gazi University, Ankara.

Polat E., (2014). Öğretmen adaylarının fatih projesi çerçevesinde e-içerik geliştirme becerilerinin değerlendirilmesi. [Evaluation of e-content development skills of teacher candidates within the framework of the FATiH project]. (Master's Thesis), Firat University, Elazı ğ. 